Nepalese Culture

Vol. XIV : 26-37, 2021

Central Department of NeHCA,

Tribhuvan University, Kathmandu, Nepal

DOI: https://doi.org/10.3126/nc.v14i0.35423

\title{
Shivalinga : Symbolism, Typology and a Glance on Licchavi Shivalingas
}

\author{
Sandhya Khanal Parajuli (Ph.D). \\ Lecturer, Central Department of Nepalese History, \\ Culture and Archaeology, T.U \\ E-mail: sandhya.khana1999@gmail.com
}

\begin{abstract}
The images that look like a male and a female organ have been discovered around the world and are marked as sacred since the establishment of civilization. What does this image symbolize? Why do Hindus worship it and why is it personified as lord Shiva? The concentration to answer these queries through descriptive analysis of the linga is tried in this article. Lingas are found in various civilizations, including Indus valley, but the perception varies. Its tangible and intangible form and several varieties are its typology. This article is mainly based on symbolism of linga for various societies and for earlier Aryans. Linga, though varies in form, is a phallic symbolism of creation which was not accepted by the Aryans at first due to its nudity and straightforwardness. But after the realization of its core theme that the linga is the composition of prakriti and purush, it made them eager to establish through its reformed reality rather than his anthropomorphic form in honor of their supreme god, the creator and a destroyer, no other than lord Shiva who self-emerged as jyotirlinga. Almost all the typologies including maximum varieties of manmade lingas are found around Kathmandu valley but the choice of Licchavis for the establishement of linga with its specific typology and theme are discussed.
\end{abstract}

Key words : Linga, Yoni, Vedi, Prakriti, Purush, Sakala, Niskala, Brahmasutra, Sisnadeva, Veshar, Nagar.

\section{Introduction}

Lingas made out of stone or mud and circular discs that are alike yoni have been discovered from Mohanjodado and Harrapa. The ancient societies like Greek, Rome, Egypt, Mesopotamia and many other worshiped linga as the representation of reproduction, 
cultivator, amulets, ornaments, saver of phallus etc. Many lingas are scattered around our society and are worshiped by people. But why do Vedas not discuss about linga? Only the Upanisadh speaks about linga and the worship of linga is profoundly practiced from Epic and Pauranic period. Why did Vedic Aryans not accept linga? When and why at a later period did they accept linga? Why is linga represented as lord Shiva and not the other God? How are the lingas made? What type of lingas did the Licchavi society prefer? These statements are identified as the problems in this article. Finding out the solution through the review of literatures and making analysis of Licchavi lingas through survey and their judgement through mentioned pratima lakshan is the theme of this article.

\section{Methodology}

This article is a qualitative research. The research of different aspects of lingas is conducted through using primary and secondary sources. Several sites of Kathmandu valley that included Shivalingas are visited. Their epigraphs are collected. And their photographs are taken. Like-wise Vedas, Upanisadas, Epics, Puranas and several books, journals, articles published about the Shivalingas are reviewed as secondary sources. The review of published as well as unpublished literatures have been done.

Shivalingas were observed in order to do analysis of typology of its art, its pratima lakshan and material used to make lingas through ages. Among the number of Shivalingas of Kathmandu valley, Lichhavi Shivalingas are focused. Selective samples of Licchavi lingas with inscriptions were chosen. Comparing them with the lingas without inscriptions, its typology, style of the time, materials selected and its theme are discussed.

Information collected from both sources are analysed and discussed in descriptive manner, in a systematic form. The references taken from secondary sources are mentioned in the content, as per rule of methodology of research along with bibliography. In this way this research article is prepared following scientific research methodology.

\section{Symbolism of Linga through Ages}

The male organ is known as phallus (linga). To worship the symbolic organ that is alike phallus is known as phallicism (lingopasana) and the group of people who worship it is known as phallic cult (linga sampradaya). Linga is the symbolism of reproduction, cultivation and creation. In many societies, it is the symbolism of religion, tradition and culture. People of Neolithic age worshiped linga to improve their cultivation (Mishra, 1980: 693). During the excavation of Mohenjodado and Harrapa, lingas made out of stone and mud as well as circular discs, similar to a female organ (yoni) were discovered (Huntington, 1985: 17). In ancient Egypt, god Min was shown with the erected phallus as a god of fertility; in ancient Greek, god Priapus was considered as the god of procreation and is shown with a huge phallus. In ancient Rome, the phallus was used as a decorative item in architecture and 
also as an ornaments and amulets. Babylonians worshiped phallus as the god of cultivation and procreation. While linga symbolized different themes to different societies of the world, the matter of concern is the perception of people of Sindhu regarding it. For this, one should concentrate on the verses of Vedas.

The word Sisnadeva is mentioned in few verses of Rigveda that symbolizes linga. Aryans in the verses 7, 21, 5; 10, 99, 3 and 10, 27, 19 of Rigveda, have requested lord Indra to protect them from the demons or the enemies who are the worshipers of Sisna or linga and to capture their city (Luitel, $2076: 551,975$ ). These verses help to analyze that beside Aryans, there were a group of people who were identified as Non Aryans, Dravidians or a group who worshiped linga, whom the Aryans hated. Dravidians were the resident of Sindhu, who after the downfall of the civilization migrated to the Eastern and Southern part of India, and were the worshipers of linga, while Aryans during the time, were the worshipers of Rudra (Das, 1925:278). Atharva Veda's verses 3, 4, 23; 4,2,25; 7,3,6 explains about the worship of yoni and womb of a mother in order to conceive a healthy child (Pandayay, 1996: 30,53,101)), but is silent about linga. Likewise no other Vedas discuss about linga, nor do the Brahmanas. In this way Vedic literature lack the verse regarding linga.

The age of Upanisadh is known as the analytical age of philosophy, rather than Havana (sacrifice). It is Upanisadh, that for the first time explains about the philosophical value of linga and yoni. Kathopanisadh, Swetaswetarupanisadh, Rudraupanisadh, Rudrahridayaupanisadh explains about linga and yoni These Upanisadhs define linga and yoni as a supreme form of lord, the prakriti and purush, male and female, Rudra and Uma and defines that, "the creation of the world is the product of these two". In Rudhrahridayaupanisadh 23, "Rudrolingamumapitham, tasmaitasyainamonamah:" or vow is offered to Shiva in the form of linga and Uma in the form of pithika (Rana, $3: 11$ ). In the same way, in another statement of same Upanisadh, it is mentioned that, "Chandals are the pran lingis, they know linga very well, so they are not Chandalas but lord Shiva", (Rana, $3: 106$ ). This proves that, Non Aryan's culture of worshipping of linga that had been cultivated and preserved since the emergence of civilization, were accepted by the Aryans only during the Upanisadh age. Though philosophically the Aryans accepted the concept, but the practice of worship of linga was yet not comfortable for them.

Worshiping and establishment of linga were found during Epic period. Ravana was a great worshiper of linga. Ram and Hanuman had established linga. Likewise, the explanation of importance of linga as well as its worship was explained by Upamanyu to lord Krishna. Worship of lingas by Kunti, Madri, Arjuna are few of the examples of this period.

Pauranic age gives plenty of explanation of linga. Puranas explains about its importance, pratima lakshana of making linga and pithika, vidhan of its establishment, 
self-emergence of several lingas, establishment of linga by gods, ganas and ashuras. Many interesting stories about linga are explained in Shivapurana, Lingapurana, Skandnapurana, Vamanapurana, Himawatkhandapurana, Self-emergence of lord Shiva as jyotirlinga infront of Brahma and Vishnu to close the discussion about their supremacy, the first worship of linga by them, explanation about importance of linga and the linga as the essential means of salvation rather than his anthropomorphic form explained by lord Shiva, providing of her yoni as aasana for linga by Uma, establishment of linga in Darubana which had fallen due to the curse of Rishis and many more stories explained in Puranas encouraged devotees to further establish lingas. But the essential theme of almost all lingas (manmade lingas) of the earlier period is that, they were implemented originally like a phallus, i.e. Linga of Guddimallam (Sunga Period) and Kushana period. Coming to the Gupta period, the structure that resembled like phallic was reformed through the use of brahmasutra. This was the best theme chosen by the Aryans, to avoid nudity, openness and straightforwardness of linga since the starting of civilization.

\section{Typology of Linga}

Lord Shiva is worshiped in two forms: Shaakaar and Niraakaar.

Shaakaar form is the anthropomorphic form of lord Shiva like Shiva, Uma Maheshwor, Bhairav, Nateshwora etc. Niraakaar form is the Linga form.

Niraakaar form of lord Shiva or the linga are of various types :

Chalalinga: Linga that can be moved or settled after its worship. Achalalinga: Linga that are fixed or cannot be moved (Roa, 1997: 75-76).

Niskalalinga: Linga that look like phallus or plain linga without face. Sakalalinga: Llinga on which anthropomorphic form of Shiva is carved. Mishralinga: Linga with one to four or five faces (Mishra, 1987:264).

Linga varies according to the material chose for making : Mridmayalinga: Linga made up of mud. Lauhajalinga: Linga made up of metals like gold, silver, copper, iron etc, Ratnajalinga: Linga made up of gems like topaz, pearl, ruby etc, Darujalinga: Linga made up of wood. Sailajalinga: Linga made up of stone. Kshyanikalinga: Linga made by honey, rice, sandal paste, flower etc for short period of time (Rao,1997: 75-77).

Further, there are varieties of Achalalingas:

Swoyambhulinga: Lingas which are self-emerged, which needs no repairing, if damaged caused through animals or nature. Daivikalinga: Linga which is believed to be established by god, which resembles like the burning fire or the anjali mudra. Ganapalinga: Linga which is believed to established by the ganas and resembles like cucumber or 
marmalos (bel). Arshalinga: Linga which is established by Rishi and resembles like coconut (Rao, 1997, 83-86). Banalinga: Linga which are found in river bank like Gandaki, Varanasi, Narvada, Saraswoti etc and that might be of any shape and size (Shreevastav, 1996 :71). Manushlinga: Linga made and established by men and are found in maximum numbers.

Manushlinga is composed of three parts: Brahma pith: the bottom square part that remains under the ground or attached to pithika/jalahari and is also known as Brahma Bhaga or Lord Brahma. Bhadra pith: the middle octagonal part and is also known as Vishnu Bhaga or lord Vishnu. And the Bhoga pith : the upper cylindrical part, where puja is offered and is also known as Puja Vagha, Rudra Bhaga or lord Rudra (Vishnudharmottarpurana, 1998, 74 : 2-3). On each Bhoga pith or Puja Bhaga, there must be brahmasutra carved as an alternative symbolism of uppermost part of erected phallus. Agama explains that, Manushalinga in absence of brahmasutra is incomplete and do not deserve worship. Among the above mentioned lingas, Swayambhulinga is categorized as uttamottamalinga or the best, according to Supravedagam and Puranas.

Manus lingas are plain as well as with faces. The linga with face/faces is called Mukhlinga. Mukhalinga contains one to five faces. Four faces are carved in their specific directions. Tatpurush, Aghor, Sadhyojat, Vamadev from east in a clockwise direction, and are carved on Bhoga pith or Puja Bhaga of a linga. The fifth face is known as Ishan and is mostly invisible. Rupmandana recommends to make linga with one, three and four faces but not with two or five faces (Shreevastav, 1966: 177) whereas, Rao suggests for five faces (Rao, 1997 : 98). Lingas are further more categorized into different varieties as mini size lingas are carved on the Puja Bhaga. Astotarsayalinga: On Puja Bhaga of linga, one hundred and eight lingas are carved. Sahasralinga: On Puja Bhaga of linga, one thousand one lingas are carved. Dharalinga: On Puja Bhaga of linga, five to sixty four lines or lingas are carved. Likewise linga even varies as per its length and width.

The pedestal of linga is another essential part of linga. It is known as pithika, vedi, yoni or jalari, the representation of Uma. Linga is incomeplete without pithika. Various types of pithikas are described in different texts. Lingas are also categorized according to the structure of pithika. They are : Nagar pithika: Linga with a rectangular pithika. Vesharpithika : Linga with a circular pithika and Dravinapithika: Linga with an octagonal pithika.

\section{Linga Pithika Pratima Lakshana}

It is compulsory to follow the rule or pratima lakshana while making of image. Images without pratima lakshana are mentioned as worthless. Various texts have been described about the lakshans of linga and pithika. According to Linga Purana, chala linga must be equal to or more than one angul but not less than one angul of the person who establish or worship. Whereas, achala linga should be equal to twelve angul and not less than that of establisher (Linga Purana, 2075: 28). Likewise Rupmandana suggests for making 
chala linga between one to eleven angul and achala linga equal to one haat, and this type of linga should not be established at home but at the temple or an open place (Shreevastav, 1996: 162-163). Lakshana for making of lingas out of different materials and their size are mentioned in Matshyapurana. Rupmandana describes the the lakshana of brahmasutra. It explains that, Rudra Vagh of a linga should be divided into sixteen parts and on its tenth part, brahmasutra should be carved (Shreevastav, 1996: 170). Lakshans for making of one to five faces in specific directions with specific weapons in their hands are explained in Vishnudhormattarpurana, Rupmandana and also by Rao in his book the elements of Hindu Icoography. Likewise different lakshanas for pithika is also discussed. As the upper part of linga is representation of linga and the earlier ones were made as a replica of an erected male organ, Likewise pithika is representation of yoni and have vidhana of representing it like a yoni. Pithika should be made more than triple size of linga, and its width should be equal to the width of linga. Pithika should cover the Brahma Bhaga and should touch the end of Vishnu Bhaga, according to Rupamanda (Shreevastav, 1996: 174-176). Pihtika should always be placed facing towards north and the material used for making the pithika should be same as linga. Matshyapurana further describes about ten varieties of pithika.

For the lingas which are made to be established in Shivalaya (Shaiva temple), its specific lakshana is described in Matshyapurana. It explains about its various pramans (shape and size), but the linga equal to third part of total area of sanctrum of a Shivalaya out of its fifth part is categorized as best (Matshyapurana, $2070: 996)$. And procedure of establishing the linga on a pithika inside the Shivalaya along with adhivasana, havana and chanting of specific mantras is described in detail in Matshyapurana and Lingapurana.

\section{Licchavi Lingas and their features}

The emergence of lord Pashupatinath through jyotirlinga, mentioned in Puranas and Mahatmyas proves the antiquity of Shaivism in Nepal. Images like Uma Shiva sahit chaturmurti (third century, C.E., Nachghar), Three faced Shiva (third century.C.E., Chikha Mugal), Shiva and Shiva Parvati (third century,C.E. respectively, Ganesh temple Kirtipur), Harihara (third century,C.E., Saugal Patan), Virupakshya (fourth century,C.E., Aryaghat), Uma Maheshwor (second to fourth century, C.E., of Patan Chamunda, Deupatan, Kumveshwor, Sikubahi Patan etc) are the best examples of the earlier or Pre-Licchavi anthropomorphic or shaakaar form of lord Shiva ever found around Kathmanu Valley. While many of his shaakaar form were established around, very few example of manmade shivalinga i.e. shivalinga with four faces of Balkhu is found. Whereas sixty-four Swyambhuva lingas including lord Pashupatinath as described in Himavatkhandapurana had its presence much earlier. Before concentrating to the lingas of Licchavi period, it must be mentioned, as per the number of lingas scattered around us that, Lichhavi as well as the medieval society preferred the linga form of Shiva primarily. Secondarily they preferred Uma Maheshwor and Bhairava, where as other form of his images are in shade. 
More than hundreds of shivalinga of Licchavi period are found around Kathmandu valley. Few of them are along with inscriptions, while maximum lacks it. Shivalingas of Naravarma S.388, Kshemsundari S.390, Ratnasanga S.399, Ratnasanga (Pravhukeshwor) S.402, Panchadeval S.410, Jayalamba S.413, Gunawati S. 419, Viyjayavati S.427, Vhasmeshwor S.455, Abhirigomini S.462, Manmati S.467, are some of the lingas with inscriptions of Licchavi period (Bajracharya, 2030 : 32, 40, 50, 56, 61,62, 66, 83, 155, 171, 175). Simplicity, flexibility, less use of ornaments and decoration, Aryan face, naturality, selection of bluish black stone, use of special paste (lep), use of transparent cloth, especial use of mukuta, jatamukuta are the basic features of Licchavi images. In this article, few of the Licchavi lingas with and without epighraphic record are selected. The lingas without epigraphic record after the analysis of its similarity with the recorded one, along with the style and characteristics of the time mentioned above and its features are discussed below.

\section{Shivalinga of Gunavati S.419}

This Shivalinga
is at Lajimpat at the
southern bank of Ikshumati
river. It was established
by Gunavati, the wife
of King Manadeva in
S.419 for punyavridhi of her deceased father Kinnarvarma (Bajracarya, 2030: 66). It is now in the courtyard of a private house. It is a niskala linga (without face) established on a huge Veshar styled pithika/jalahari, a replica of a yoni. Its Brahma Bhaga is inserted inside the pithika, where as its Vishnu

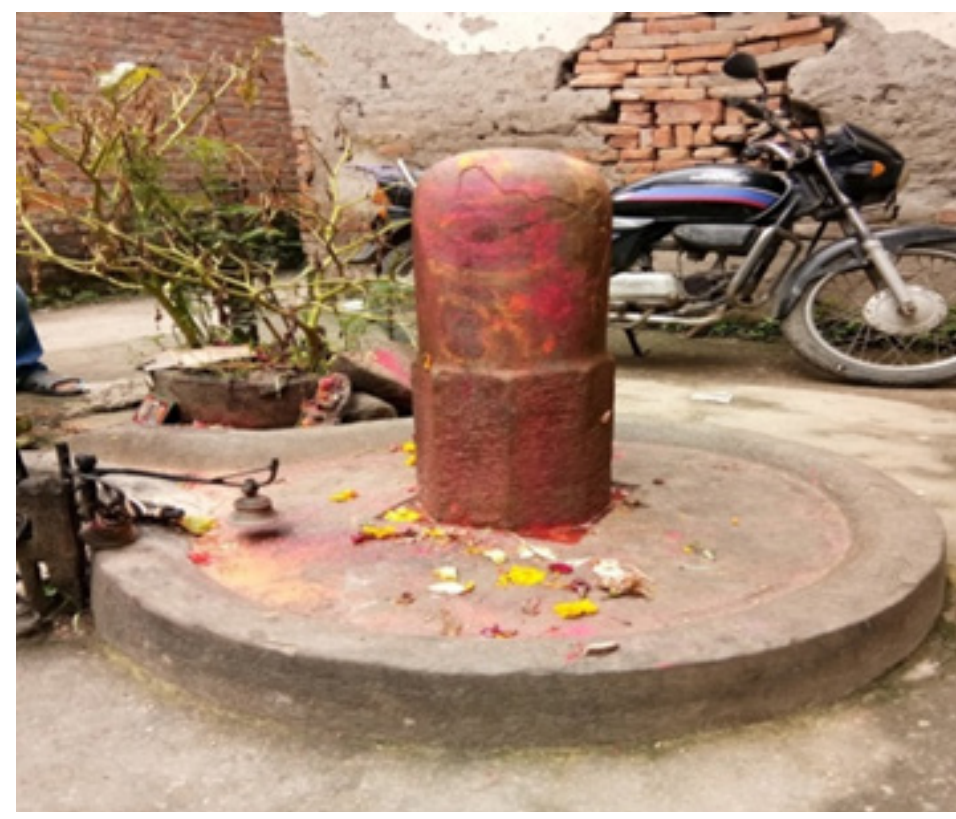
Bhaga is of octagonal shape. The plain Rudra Bhaga with some damages on the layer of paste on its top and curved lines as a mark of brahmasutra on the Rudra Bhaga can be seen. 


\section{Shivalinga of AbhirigominiS.462}

This shivalinga is establised at the southern part of Pashupatinath temple. It is known as Anuparameshwor Shivalinga. It was established by Abhirigomini, the wife of Anuparam or the mother of Bhauma Gupta for punyavridhi of her deceased husband in S.462. She also had donated land as Guthi to offer daily snan (bath), to put on oil and chandan, to offer naivedhya (food) to lord and for renovation if the linga is damaged (Bajracharya, 2030 : 171). It is a niskala linga established on a huge nagar styled pithika above the pedestal. Its Brahma and Vishnu Bhaga are invisible while a short part of a Rudra Bhaga is seen.

\section{Shivalinga of Chasyalhiti}

This shivalinga is in Chasyal hiti premise, of Chyasal tole of Patan. It is a linga without the epigraphic record and is established in-front of ancient image of Gajalaksmi ( $1^{\text {st }}$ Century B.C.). It is a niskala linga attached to a huge Veshar styled pithika. Its octagonal Vishnu Bhaga and a cylindrical Rudra Bhaga with brahmasutra is seen. The linga has shining paste or lep throughout the linga and pithika. This linga resembles like the lingas of Gunawati of Lajimpat, Vijayawati of Suryaghat, Natheshwor linga established by Manmati at Mrigasthali and many other lingas of Licchavi period with inscrition. The style compared to the above mentioned lingas, the brahmasutra carved on it and the paste or lep applied to it, supports to categorise it as a Licchavi linga and can
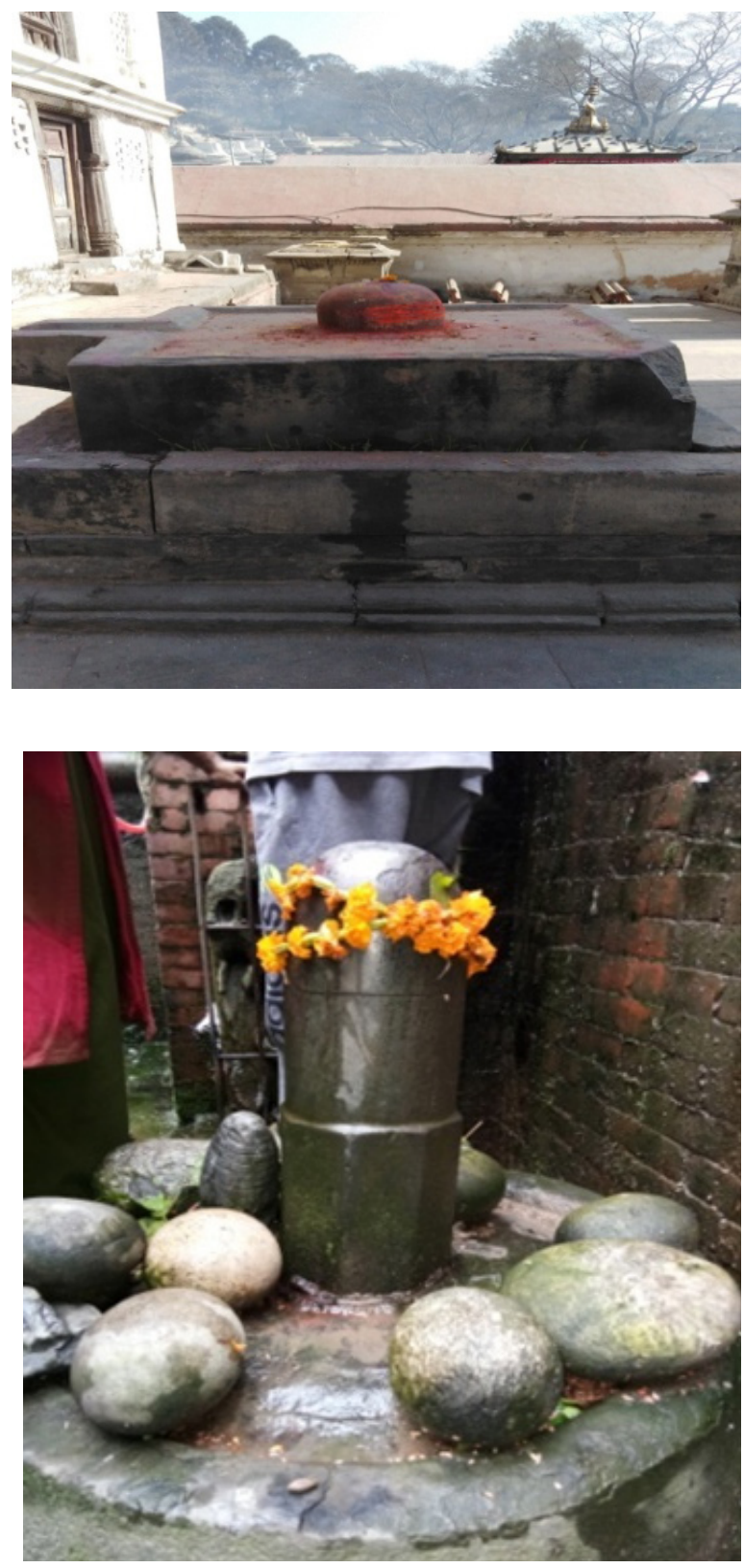
be dated around $5^{\text {th }} / 6^{\text {th }}$ C.E. 


\section{Ekmukha Shivalinga}

This ekmukha shivlinga is at Mrigasthali opposite to Pashupatinath temple. Few mukha lingas (lingas with face/faces) of Licchavi period have been found. It is one of the best example of earlier shivalinga with face. The linga is established on huge Veshar styled pithika. The face is carved in between the top and upper part of Rudra Bhaga as suggested in Rupmandana (Shreevastav,1996:170). Long Aryan styled nose (which is now damaged when it was attempted to steal in early 1986), three eyes, elongated earlobes, stretched out lower lip, jatamukuta with half-moon on his head, hanging down loops of hair back from the ears, single line of rudrakhya mala on his neck, folds of skin in the neck along with its simplicity, really attracts anyone's concentration. This Shivalinga belongs to $5^{\text {th }}$ century C.E. (Bangdel, 1989 : 302). The specially carved Jatamukuta on lord Shiva's head with the specific characteristic of Licchavi period and its simplicity proves too.

\section{Panchamukhi ShivalingaT}

Shivalinga with four faces are also known as panchamukhi Shivalinga. This type of lingas of Licchavi period are few in numbers and can be counted. This shivalinga was established at the middle of road on the way to Mrigasthali, immediately after crossing the brigde of Bagmati river from Aaryaghat of Pashupatinath. This panchamukhi Shivalinga of $5^{\text {th }}$ century C.E. was stolen in 1987 . So the analysis it is only possible through the picture published in Stolen Images of Nepal (Bangdel, 1989 : 207-209). The linga stands without pithika. Its long octagonal Vishnu Bhaga and Rudra Bhaga with four faces carved on it help to assume about its long Bhamha Bhaga beneath the earth. Four aspects of Shiva in the linga is carved with different elaboration of hair as well as jatamukuta and expressions. Each hands of Tatpurush, Aghor, Sadyojata, Vamadev Shiva respectively from east to north in clockwise directions holds rudrakshya mala along with avaya mudra and kalash (water-pot). As aagama describes that, the face/faces of Shiva in the linga should be attached to his body and should be depicted till the chest (Rao, 1997: 98). As described in the text, four faces of Shiva in the linga are attached to its shoulders and hands out of their chest. The selection of bluish black stone along with polish or lep, varieties of elaborated hair style with jatamukut, mukut and especially small circular knots of hair carved on southern face of Shiva that resembled like the hair style of Rahu of Vishnuvikranta image of Lajimpat now in

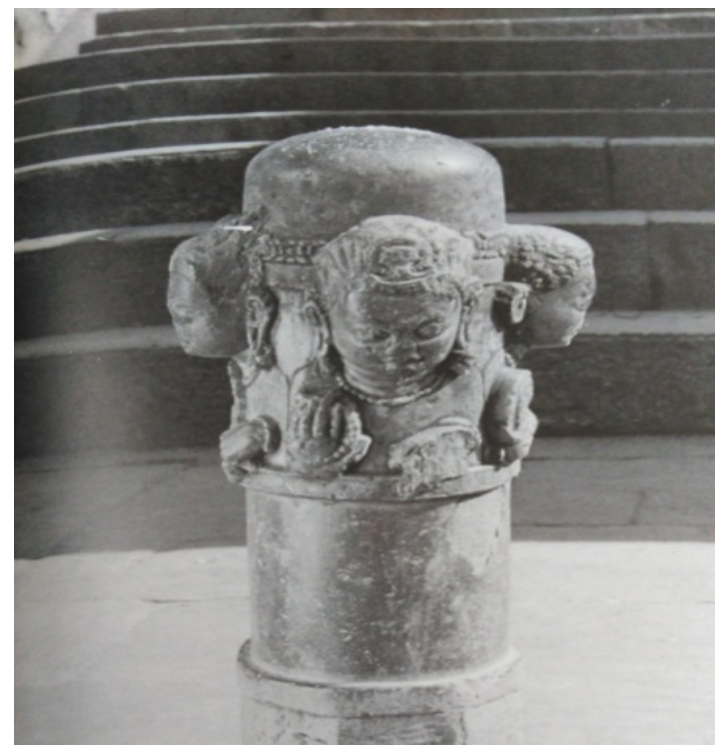


National Museum, Chauni, single line of rudrakshya mala on the neck and its simplicity supports to prove the linga to be of early Licchavi period.

\section{Discussion}

After the analysis of few samples of the Lichhavi Shivalingas, an outline of its features are traced, which are as follows :

Nepalese society of Licchavi period especially preferred niraakar form of Shiva (the linga or the composite form of Siva and Uma) rather than his Shaakar (anthropomorphic) form.

Maximum Shivalingas of Licchavi period with Brahma Bhaga with square part under the ground, Vishnu Bhaga along with long octagonal part and Rudra Bhaga with cylindrical part with or without face/faces, signifies specific Licchavi character, which gradually vanished after this period.

Licchavi Shivalingas with octagonal Vishnu Bhaga and cylindrical Rudra Bhaga along with carving of brahmasutra and the face/faces as suggested in the related texts proves they are made through following pratima lakshanas.

Lingas that resembles like phallus, as in earlier Indian continent are not discovered.

Almost all the Licchavi Shivalingas are either established on a Veshar or a Nagar style pithika. Making of Nagar pithika was famous in Northern India and Dravina in Southern India, where as Veshar style, the mixture of Nagar and Dravina was famous between these areas (Gurung, 2076 : 8). Nepal during the Licchavi period chose both Nagar and Veshar style and was very popular. The pithika with Dravina style are not found in Nepal till the date. The pithika with Veshar style existed till long period of time, while Nagar style vanished after the Licchavi period.

It is the uniqueness of the Licchavi art to choose the huge size of pithika. (Veshar or Nagar).

The texts like Vishnudharomottarpurana, Rupmandana and many more suggested to make the images of Shiva in linga, with specific weapons but Licchavis preferred Shiva with abhaya mudra along with rudrakshya mala and kalash or kumaba the most.

Selection of bluish black stone for making of linga, application of paste (lep) in linga as well as in pithika and the simplicity found in its images proves the continuation of Licchavi art as in other images of the period.

The motive of etablishment of Shivalings during Licchavi period are various. They are established for the welfare of people and the king. Punya vridhi of the person who 
established, their parents or the deceased members and most of the lingas are established for salvation.

\section{Conclusion}

This article helped to draw the conclusion regarding the the niraakar representation of lord Shiva or the linga, the symbolism of creation through different ages to different societies as well as to Aryans. It was very hard for Aryans to accept linga as phallus, so they accepted in a reformed theme. However, the selection of same theme was chosen by the Licchavis in a typical manner.

While the phallus or linga, for the world symbolised fertility, cultivation, amulets and for Dravidians the symbolism of creation, it was a nude and shameful replica of a male organ to Aryans, who not only denied this symbol but hated the people who worshiped it. Even after the realization of its core theme as prakriti and purush, the symbolism of creation or the means of salvation, its straightforwardness still made them hesitate to worship its nudity. So they reformed it through bramhasutra. Natural and Manush lingas made through following various prescribed lakshanas are its typology, still the Syowambhuva or the naturally formed ones are the best. But the manmade ones without following the lakshanas are worthless. Licchavi society among various forms of Shiva preferred linga the most. Out of its various type, linga with Nagar and Veshar pithika with or without face along with following lakshanas and characters of the time are its speciality.

\section{References}

Bangdel, L.S. 1989 A.D. The Stolen Images of Nepal. Kathmandu : Royal Nepal Academy.

Das, A.C. 1925 A.D. Rgvedic India. Calcutta.

Huntington, S.L. 1985 A.D. The Art of Ancient India. New York : Weather Hill.

Rao, G. N. 1997 A.D. Elements of Hindu Iconography. V.II, P.I. Delhi : Motilal Banarasidass Publishers.

Rao, G. N. 1997 A.D. Elements of Hindu Iconography. V.II, P.II. Delhi : Motilal Banarasidass Publishers.

गुरुज्ञ, जगमान. वि.सं. २०७६. राष्ट्र, राष्ट्रियता र सर्वधर्मसमभावका प्रतीक भगवान श्रीपशुपतिनाथ. पशुपति दर्पण. वर्ष.१, अड्र.१, काठमाडौं : पशुपति क्षेत्र विकास कोष।

पाण्डेय, राजबहादुर. (अनु.). सन्. १९९६. अथर्ववेद. दिल्ली : डायमण्ड पाँकेट बुक्स ।

मत्स्यपुराण. वि.सं. २०७०. गोरखपुर : गीताप्रेस ।

मिश्र, इन्दुमती. सन्. १९५७. प्रतिमा विज्ञान. भोपाल : मध्य प्रदेश हिन्दी ग्रन्थ अकादमी। 
मिश्र, जयशंकर. सन्. १९५०. प्राचीन भारतका सामाजिक इतिहास. पट्ना : हिन्दी ग्रन्थ एकाडमी। राणा, भुवनसिंह. (सं.). (मिती नभएको). 905 उपनिषद. (भाग ३), दिल्ली : डामण्ड पाकेट बुक्स प्रा.लि. लिड़पराण. वि.सं. २०७४. गोरखपुर : गीताप्रेस । लुईटेल, तिलकप्रसाद. (अनु.). वि.सं. २०७६. ॠट्वेद. काठमाडौं : विद्यार्थी पुस्तक भण्डार । वज्राचार्य, धनवज्र. (वि.सं. २०३०). लिच्छविकालका अभिलेख. काठमाडौं : नेपाल र एशियाली अनुसन्धान केन्द्र

श्रीवास्तव, बलराम. रुपमण्डन्. सन्. १९९६. दिल्ली : मोतीलाल बनारसीदास । क्षेमराज, श्रीकृष्ण दास. (सं.). (सन्. १९९६). विष्णुधर्मोत्तरपुराण. दिल्ली : नाग प्रकाशन । 